\title{
REPEAT BREEDER PADA SAPI KRUI DI KECAMATAN PESISIR SELATAN KABUPATEN PESISIR BARAT
}

\author{
Repeat Breeder of Krui Cattle in Pesisir Selatan District of Pesisir Barat Regency \\ Luluk Adria Ningrum, Madi Hartono, Sri Suharyati, Siswanto \\ Department of Animal Husbandry, Faculty of Agriculture Lampung University \\ Soemantri Brojonegoro No.1 Gedong Meneng Bandarlampung 35145 \\ e-mail: lulukadr@gmail.com
}

\begin{abstract}
Research on repeat breeder in Krui Cattle in Pesisir Selatan District of Pesisir Barat Regency was held on 23 December 2019 until 15 January 2020 with 2 inseminators, 166 Krui Cattles belong to 75 farmers. The purpose of this research were to know: 1) the value of repeat breeder in Krui Cattle in Pesisir Selatan District of Pesisir Barat Regency, and 2) the factors and the magnitude of the factors which disturb repeat breeder of Krui cattle in Pesisir Selatan District of Pesisir Barat Regency. Data was analysed by logistic regression using SPSS (Statistics Package for Social Science) program. The result showed that repeat breeder of Krui cattle in Pesisir Selatan District of Pesisir Barat Regency was 10,24\%. Factors that affect the repeat breeder were farmers education that negatively associated with factor value of 5,757; the location of the cage from the farmers house that positively associated with factor value of 0.090; and age of first mating that negatively associated with factor value 1,088 .
\end{abstract}

Keywords: Affecting Factors, Krui cattle, Magnitude factors, Pesisir Selatan, Repeat breeder

\begin{abstract}
ABSTRAK
Penelitian mengenai repeat breeder pada Sapi Krui di Kecamatan Pesisir Selatan Kabupaten Pesisir Barat dilaksanakan pada 23 Desember 2019 sampai 15 Januari 2020 terhadap 2 orang inseminator dan 166 ekor Sapi Krui betina milik 75 orang peternak. Penelitian ini bertujuan untuk mengetahui: 1)-besarnya repeat breeder pada Sapi Krui di Kecamatan Pesisir Selatan Kabupaten Pesisir Barat dan 2) faktor-faktor dan besarnya faktor yang mempengaruhi repeat breeder pada Sapi Krui di Kecamatan Pesisir Selatan Kabupaten Pesisir Barat. Analisis data yang digunakan adalah logistic regression dengan aplikasi SPSS (Statistics Packet for Social Science). Hasil yang diperoleh adalah kejadian repeat breeder pada Sapi Krui di Kecamatan Pesisir Selatan Kabupaten Pesisir Barat sebesar 10,24\%. Faktor-faktor yang mempengaruhi repeat breeder yaitu pendidikan peternak yang berasosiasi negatif dengan besar faktor 5,757; letak kandang dari rumah yang berasosiasi positif dengan besar faktor 0,090; dan umur pertama kali dikawinkan yang berasosiasi negatif dengan besar faktor 1,088 .
\end{abstract}

Kata Kunci: Besarnya faktor, Faktor yang mempengaruhi, Pesisir Selatan, Repeat Breeder, Sapi Krui

\section{PENDAHULUAN}

Kebutuhan daging di Indonesia semakin meningkat sejalan dengan meningkatnya jumlah penduduk dan kesadaran masyarakat mengenai pentingnya protein hewani. Konsumsi daging per kapita tahun 2017 sebesar $0,469 \mathrm{~kg}$, atau meningkat dari konsumsi daging sapi per kapita tahun 2016 sebesar 0,417 kg (Ditjen PKH, 2018). Angka tersebut menyebabkan kebutuhan daging sapi nasional sampai saat ini belum dapat terpenuhi sehingga masih harus ditutupi dengan keberadaan sapi impor baik dalam bentuk sapi bakalan maupun daging sapi beku.
Sapi Krui merupakan salah satu sapi lokal yang memiliki tubuh berukuran kecil. Sapi Krui merupakan jenis sapi lokal yang telah mengalami perkembangbiakan secara alami di daerah Krui Kabupaten Pesisir Barat. Masyarakat Kabupaten Pesisir Barat menyebut sapi yang ada dengan sebutan Sapi Krui atau "Jawi Peghia" yang artinya sapi kecil. Sejarah dan asal usul Sapi Krui ini belum diketahui. Diduga sapi ini berasal dari India yang dibawa bangsa Hindu ke Indonesia seperti banteng yang dijinakkan.

Provinsi Lampung merupakan daerah yang memiliki potensi untuk pengembangan usaha di 
bidang peternakan yang cukup tinggi. Hal ini dinilai dari jumlah populasi ternak potong di Provinsi Lampung yang cukup tinggi. Menurut Ditjen PKH (2018), populasi sapi potong di Lampung mencapai 679.795 ekor yang tersebar di berbagai wilayah. Di daerah Kabupaten Lampung Barat khususnya, populasi Sapi Krui berjumlah 6.814 ekor yang tersebar di berbagai kecamatan (Dinas Pertanian Kabupaten Pesisir Barat, 2018).

Penduduk Pesisir Barat memanfaatkan Sapi Krui sebagai sapi tipe pedaging dalam beberapa acara besar, jika hal tersebut dilakukan terus menerus dan tanpa dilakukan pelestarian terhadap Sapi Krui tersebut maka lambat laun akan menyebabkan penurunan populasi Sapi Krui secara signifikan dan dapat menyebabkan kepunahan. Salah satu upaya yang dapat dilakukan untuk melestarikan Sapi Krui yaitu dengan menerapkan teknologi reproduksi yang disebut dengan Inseminasi Buatan (IB). Pelaksanaan IB diharapkan mampu meningkatkan efisiensi reproduksi, sehingga populasi Sapi Krui dapat meningkat.

Rendahnya efisiensi reproduksi seringkali menjadi permasalahan utama dalam beternak sapi potong. Efisiensi reproduksi yang rendah menandakan adanya gangguan reproduksi, salah satunya repeat breeder. Repeat breeder merupakan keadaan sapi betina yang mempunyai siklus estrus normal dan telah dikawinkan paling tidak tiga kali dengan pejantan atau semen pejantan fertil tetapi belum bunting tanpa disertai gejala klinis dari penyakit atau abnormalitas alat reproduksi (Toelihere, 1993)

Terjadinya repeat breeder dapat disebabkan oleh beberapa faktor, faktor inseminator dapat berupa kurangnya keterampilan yang dimiliki oleh inseminator, pendidikan inseminator, waktu inseminasi yang tidak tepat atau penggunaan semen yang tidak berkualitas. Faktor ternak dapat berupa kerusakan alat-alat reproduksi karena penyakit, kelainan fungsi hormonal dan kelainan bentuk anatomis dari alat-alat reproduksi, sehingga kurang/tidak berfungsi (Robert, 1986; Copelin et al., 1988). Faktor peternak dapat berupa manajemen pemeliharaan seperti kurangnya pakan yang diberikan (sejak pedet/anak sampai dewasa), manajemen kesehatan meliputi pemeriksaan kesehatan yang tidak dilakukan secara rutin seperti pengecekan keadaan ternak apabila ternak mengalami penurunan nafsumakan, terdapat luka dan gangguan abnormalitas pafa fisik maupun sikap ternak, kebersihan kandang yang kurang terjaga, sanitasi kandang yang dilakukan sesekali dalam kurun waktu tertentu, serta pemahaman mengenai estrus, tidak akuratnya deteksi estrus sehingga mengakibatkan keterlambatan pelaporan mengenai adanya gejala birahi (Windig et al., 2005).

Kejadian kawin berulang melanda hampir di seluruh dunia, yaitu berkisar antara 5,533,3\% (Gustafsson dan Emanuelsson, 2002). Faktor-faktor yang mempengaruhi repeat breeder berasal dari peternak, ternak dan inseminator. Hasil penelitian Yuliana (2000) menunjukkan bahwa tingkat kejadian repeat breeder dengan kriteria sapi perah yang telah diinseminasi tiga kali atau lebih di KPBS Bandung Jawa Barat sebesar 19,4\% dengan faktor-faktor yang mempengaruhi frekuensi pemberian hijauan, lama laktasi, selang beranak, distokia, bangsa sapi, birahi pertama setelah beranak dan skor kondisi tubuh. Hasil penelitian Astuti (2008) menunjukkan bahwa tingkat kejadian repeat breeder sapi potong di Kecamatan Terbanggi Besar Kabupaten Lampung Tengah sebesar 9,22\% dengan kriteria kategori repeat breeder sapi potong yang telah diinseminasi empat kali atau lebih. Angka tersebut lebih rendah jika dibandingkan dengan penelitian Juliana (2015) dimana nilai repeat breeder pada Sapi Bali di Kabupaten Pringsewu sebesar 19,85\% dengan kriteria kategori repeat breeder yang telah dinseminasi lebih dari dua kali. Hasil penelitian Astuti (2008) menunjukkan bahwa tingkat kejadian repeat breeder di Kecamatan Terbanggi Besar, Kabupaten Lampung Tengah dipengaruhi oleh umur pertama kali dikawinkan, birahi pertama setelah melahirkan, perkawinan postpartum, luas kandang, pendidikan inseminator dan jumlah akseptor.

Atas dasar berbagai latar belakang yang telah disebutkan maka penelitian repeat breeder pada sapi Krui di Kecamatan Pesisir Selatan Kabupaten Pesisir Barat dilakukan untuk mengetahui: 1)-besarnya repeat breeder dan faktor-faktor dan besarnya faktor yang mempengaruhi repeat breeder pada Sapi Krui

\section{MATERI DAN METODE}

\section{Waktu dan Tempat Penelitian}

Penelitian ini dilaksanakan pada 23 Desember 2019 sampai 15 Januari 2020, terhadap ternak, inseminator dan peternak yang terdapat di Kecamatan Pesisir Selatan Kabupaten Pesisir Barat. 


\section{Materi}

Materi yang digunakan adalah lembar kuisioner untuk ternak, peternak dan inseminator. Variabel dependen yang digunakan adalah nilai repeat breeder (Y) pada Sapi Krui. Variabel independen yang digunakan untuk data inseminator, peternak dan ternak adalah pendidikan inseminator (X1), lama menjadi inseminator (X2), tempat pelatihan (X3), jumlah akseptor (X4), jarak menuju akseptor (X5), produksi straw (X6), lama thawing (X7), ketepatan IB (X8), alasan beternak (X9), pendidikan peternak (X10), lama beternak (X11), pernah mengikuti kursus (X12), jenis hijauan (X13), frekuensi pemberian hijauan (X14), jumlah hijauan (X15), jumlah konsentrat (X16), jumlah pemberian air (X17), letak kandang (X18), bentuk dinding kandang (X19), bahan atap (X20), bahan lantai kandang (X21), luas kandang (X22), sanitasi kandang (23), umur sapi (24), skor kondisi tubuh (X25), umur pertama kali dikawinkan (X26), birahi pertama setelah beranak (X27), perkawinan postpartum (X28), gangguan reproduksi (X29), status reproduksi (X30) dan pemeriksaan kebuntingan (X31).

\section{Metode}

Metode penelitian yang digunakan adalah metode survey dengan teknik pengambilan data secara sensus. Semua Sapi Krui betina berusia di atas dua tahun yang telah diinseminasi dan merupakan Sapi Krui asli di Kecamatan Pesisir Selatan Kabupaten Pesisir Barat digunakan sebagai sampel. Data yang digunakan adalah data primer dan data sekunder. Data primer diperoleh dari pengamatan secara langsung mengenai manajemen pemeliharaan Sapi Krui, kemudian melakukan wawancara pada inseminator dan peternak di Kecamatan Pesisir Selatan Kabupaten Pesisir Barat. Data sekunder merupakan data yang diperoleh dari recording milik inseminator. Repeat breeder ditentukan dengan menghitung jumlah Sapi Krui betina yang berumur lebih dari dua tahun yang telah diinseminasi tiga kali atau lebih namun tidak terjadi kebuntingan, kemudian jumlah yang diperoleh dibagi dengan jumlah seluruh Sapi Krui betina yang berumur lebih dari dua tahun dan yang telah diinseminasi, kemudian dikalikan seratus persen.

Analisis data yang digunakan dalam penelitian ini adalah analisis logistik regresi, yang sebelumnya dilakukan pengkodean terhadap data inseminator, peternak dan ternak. Hal ini dilakukan untuk memudahkan analisis, setelah itu data diolah dalam program SPSS (Statistics Packet of Social Science) (Sarwono, 2006). Variabel dengan nilai P terbesar dikeluarkan dari penyusunan model kemudian dilakukan analisis kembali sampai didapatkan model dengan nilai $\mathrm{P}<0,10$.

\section{HASIL DAN PEMBAHASAN}

\section{A. Gambaran Umum Inseminator, Peternak dan Ternak}

Berdasarkan hasil survey yang telah dilakukan menurut variabel pada tingkat inseminator, peternak dan ternak dapat dilihat pada Tabel 1.

Berdasarkan Tabel 1, terdapat dua orang inseminator, 75 orang peternak dan 166 ekor Sapi Krui betina yang berusia diatas dua tahun dan telah di IB. Pendidikan formal inseminator yaitu lulus sekolah menengah atas (SMA) sebanyak satu orang (50\%) dan lulus S1 Kedokteran Hewan satu orang (50\%). Rata-rata lama menjadi inseminator yaitu $4 \pm 2,82$ tahun, tempat pelatihan inseminator antara lain di BIB Lembang (50\%) dan Universitas Airlangga (50\%). Rata-rata akseptor sebanyak 30 ekor/bulan dan jarak menuju akseptor yaitu $20 \mathrm{~km}$. Straw yang digunakan berasal dari BIB Poncowati (66,6\%), BIB Singosari $(16,6 \%)$ dan BIB Lembang (16,6\%). Jenis kontainer yang digunakan adalah $\mathrm{DR}_{2}$ dan kontainer deppo. Penambahan $\mathrm{N}_{2}$ cair dilakukan satu dan dua kali/minggu. Rata-rata lama thawing yang dilakukan adalah $20 \pm 14,14$ detik. Ketepatan inseminator untuk melakukan IB yaitu sebanyak 129 ekor $(77,5 \%)$ tepat, sedangkan 37 (22,5\%) tidak tepat.

Alasan peternak memelihara Sapi Krui sebagai tabungan sebesar $93 \%$ dan pekerjaan utama sebesar 7\%. Pendidikan formal peternak yaitu SD sebesar 39\%, SMP sebanyak 28\% dan SMA sebesar 33\%. Rata-rata lama beternak adalah 9,466 \pm 7,634 tahun. Peternak Sapi Krui di Kecamatan Pesisir Selatan Kabupaten Pesisir Barat belum pernah mengikuti kursus mengenai pemeliharaan Sapi Krui. Selama ini pengetahuan beternak yang dimiliki berasal dari pengalaman turun temurun dan informasi dari inseminator, serta hasil diskusi antar sesama peternak yang ada di sekitar. 
Tabel 1. Hasil pengamatan variabel pada tingkat inseminator, peternak dan ternak

\begin{tabular}{|c|c|c|c|}
\hline Variabel & Hasil & Variabel & Hasil \\
\hline \multirow[t]{2}{*}{ Pendidikan Inseminator } & Sarjana: $50 \%$ & Jumlah Konsentrat (kg/ekor/hari) & $0,68 \pm 1,095$ \\
\hline & SMA: $50 \%$ & Jumlah Pemberiain Air (liter/ekor/hari) & $9,8 \pm 4,8$ \\
\hline Lama Menjadi Inseminator (Tahun) & $4 \pm 2,82$ & Letak Kandang dari Rumah (meter) & $12,3 \pm 23,8$ \\
\hline \multirow[t]{2}{*}{ Tempat Pelatihan } & A: $50 \%$ & Bentuk Dinding Kandang & Terbuka: $75 \%$ \\
\hline & B: $50 \%$ & & Tertutup: $8 \%$ \\
\hline Jumlah Akseptor (ekor/bulan) & 30 & & Umbar: $17 \%$ \\
\hline Jarak Menuju Akseptor (km) & 20 & Bahan Atap Kandang & Seng: $24 \%$ \\
\hline \multirow[t]{4}{*}{ Produksi Straw } & BIB Poncowati: $50 \%$ & & Genteng: $50 \%$ \\
\hline & BIB Poncowati, & & Asbes: $9 \%$ \\
\hline & Lembang dan & & Umbar: $17 \%$ \\
\hline & Singosari: $50 \%$ & Bahan Lantai Kandang & Tanah: $67 \%$ \\
\hline Lama thawing (detik) & $20 \pm 14,14$ & & Semen: $16 \%$ \\
\hline Ketepatan waktu pelaksanaan & Tepat: $77,5 \%$ & & Umbar: $17 \%$ \\
\hline \multirow[t]{2}{*}{ Atau pelayanan IB } & Tidak: $22,5 \%$ & Luas Kandang $\left(\mathrm{m}^{2}\right)$ & $18, \pm 13,9$ \\
\hline & & Sanitasi Kandang (kali/ekor/hari) & $1: 27 \%$ \\
\hline \multirow[t]{2}{*}{ Alasan Beternak (orang) } & Tabungan: 93\% & & $2: 57 \%$ \\
\hline & Utama: $7 \%$ & & Tidak: $16 \%$ \\
\hline \multirow[t]{3}{*}{ Pendidikan Peternak (orang) } & SD: $39 \%$ & Umur Sapi (bulan) & $67,22 \pm 26,18$ \\
\hline & SMP: $28 \%$ & Skor Kondisi Tubuh & Kurus: $26 \%$ \\
\hline & SMA: $33 \%$ & & Sedang: $72 \%$ \\
\hline Lama Beternak (tahun) & $9,466 \pm 7,634$ & & Gemuk: $2 \%$ \\
\hline \multirow[t]{2}{*}{ Pernah mengikuti Kursus (orang) } & Ya: $0 \%$ & Umur Pertama kali Dikawinkan (bulan) & $26,40 \pm 4,08$ \\
\hline & Tidak: $100 \%$ & Birahi Pertama Setelah & $2,67 \pm 1,74$ \\
\hline \multirow[t]{3}{*}{ Jenis Hijauan } & Lapang: $96 \%$ & Kelahiran (bulan) & \\
\hline & Gajah, Lapang: 3\% & Perkawinan postpartum (bulan) & $2,67 \pm 1,74$ \\
\hline & Lapang, Odot: $1 \%$ & Gangguan Reproduksi & Normal: $95 \%$ \\
\hline Frekuensi Pemberian & $1: 52 \%$ & & Abnormal: $5 \%$ \\
\hline \multirow[t]{3}{*}{ Hijauan (kali/ekor/hari) } & $2: 36 \%$ & Status Reproduksi & Induk: $86 \%$ \\
\hline & $3: 3 \%$ & & Dara: $14 \%$ \\
\hline & Adlibitum: $9 \%$ & Pemeriksaan Kebuntingan & Ya: $100 \%$ \\
\hline Jumlah Hijauan (kg/ekor/hari) & $15 \pm 7,3$ & & Tidak: $0 \%$ \\
\hline
\end{tabular}

Jenis hijauan yang diberikan yaitu $96 \%$ peternak hanya memberikan rumput lapang, $3 \%$ peternak memberikan rumput lapang dan rumput gajah, dan $1 \%$ peternak memberikan rumput lapang dan rumput odot. Frekuensi pemberian hijauan dilakukan oleh peternak sebanyak 1 kali/hari $52 \%$, sebanyak 2 kali/hari $36 \%$, sebanyak $3 \mathrm{kali} / \mathrm{hari} 3 \%$ dan yang diberikan secara adlibitum sebesar 9\%. Ratarata jumlah hijauan yang diberikan pada ternak sebanyak $15 \pm 7,3 \mathrm{~kg} / \mathrm{ekor} / \mathrm{hari}$, sedangkan ratarata pemberian air minum adalah $9,8 \pm 4,8$ liter/ekor/hari.

Letak kandang sapi dari rumah peternak rata-rata adalah $12,3 \pm 23,8$ meter. Bentuk dinding kandang yang terbuka sebesar $75 \%$, yang tertutup sebesar $8 \%$ dan yang tidak memiliki kandang sebesar $17 \%$. Bahan atap kandang $24 \%$ adalah seng, $50 \%$ adalah genteng, $9 \%$ adalah asbes dan $17 \%$ adalah peternak yang tidak memiliki kandang. Bahan lantai kandang $67 \%$ adalah tanah, $16 \%$ adalah semen dan $17 \%$ tidak memiliki kandang. Rata-rata luas kandang adalah $18,7 \pm 13,9 \mathrm{~m}^{2}$. Sanitasi kandang yang dilakukan oleh peternak sebanyak 1 kali/hari sebesar $27 \%$, sebanyak $2 \mathrm{kali} / \mathrm{hari}$ sebesar $57 \%$ dan yang tidak melakukan sanitasi kandang sebesar $16 \%$.

Rata-rata umur Sapi Krui betina produktif adalah $67,22 \pm 26,18$ bulan, skor kondisi tubuh 2 
sebanyak $26 \%$, skor 3 sebanyak $72 \%$ dan skor 4 sebanyak $2 \%$. Rata-rata umur pertama kali dikawinkan adalah 26,40 $\pm 4,08$ bulan, sedangkan rata-rata birahi pertama setelah

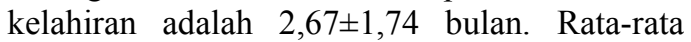

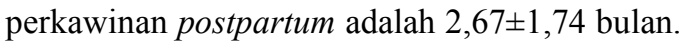
Gangguan reproduksi yang terjadi sebanyak 5\%, sedangkan sapi yang normal sebanyak 95\%. Status reproduksi Sapi Krui betina adalah induk sebanyak $86 \%$ dan dara sebanyak $14 \%$. Seluruh Sapi Krui yang diinseminasi buatan dilakukan pemeriksaan kebuntingan, kurang lebih tiga bulan setelah dilakukannya inseminasi buatan.

Nilai repeat breeder pada Sapi Krui di Kecamatan Pesisir Selatan Kabupaten Pesisir Barat sebesar 10,24\%, artinya 17 ekor sapi mengalami repeat breeder (RB), sedangkan 149 ekor lainnya tidak mengalami RB. Sapi Krui yang dinyatakan mengalami RB merupakan sapi yang telah diinseminasi buatan setidaknya lebih dari dua kali tetapi tidak mengalami kebuntingan.

\section{B. Faktor-faktor yang Mempengaruhi Repeat Breeder}

Faktor-faktor yang dapat mempengaruhi RB pada Sapi Krui di Kecamatan Pesisir Selatan Kabupaten Pesisir Barat yaitu berasal dari peternak dan ternak. Faktor-faktor yang mempengaruhi RB dari peternak adalah pendidikan peternak dan letak kandang dari rumah sedangkan faktor yang berasal dari ternak yaitu umur pertama kali dikawinkan. Faktor-faktor lainnya yang tidak mempengaruhi kejadian repeat breeder pada Sapi Krui di Kecamatan Pesisir Selatan Kabupaten Pesisir Barat yaitu, pendidikan inseminator, lama menjadi inseminator, tempat pelatihan, jumlah akseptor, jarak menuju akseptor, produksi straw, lama thawing, ketepatan IB, alasan beternak, lama beternak, pernah mengikuti kursus, jenis hijauan, frekuensi pemberian hijauan, jumlah hijauan, jumlah konsentrat, jumlah pemberian konsentrat, bentuk dinding kandang, bahan atap kandang, bahan lantai kandang, luas kandang, sanitasi kandang, umur sapi, skor kondisi tubuh, birahi pertama setelah kelahiran, perkawinan postpartum, gangguan reproduksi, status reproduksi dan pemeriksaan kebuntingan.

\section{Pendidikan Peternak}

Pendidikan peternak bermakna $(\mathrm{P}=0,085)$ dan berasosiasi negatif terhadap kejadian $\mathrm{RB}$ dengan besar faktor 5,757, dapat dilihat pada Tabel 2.

Tabel 2. Faktor-faktor yang mempengaruhi repeat breeder

\begin{tabular}{lcc}
\hline Faktor yang mempengaruhi & Signifikansi & Besarnya Faktor \\
\hline Pendidikan peternak & $\mathrm{P}=0,085$ & 5,757 \\
Letak kandang dari rumah & $\mathrm{P}=0,081$ & 0,090 \\
Umur pertama kali dikawinkan & $\mathrm{P}=0,069$ & 1,088 \\
\hline
\end{tabular}

Hal ini berarti bahwa semakin tinggi tingkat pendidikan peternak maka dapat menurunkan RB. Tingkat pendidikan ikut menentukan mudah tidaknya seseorang menyerap dan memahami pengetahuan yang diperoleh. Pada umumnya semakin tinggi pendidikan seseorang maka semakin baik pula pengetahuannya, semakin tinggi tingkat pendidikan peternak maka akan semakin tinggi kualitas sumber daya manusia, sehingga akan semakin tinggi pula produktivitas dan kinerja usaha peternakan. Hasil penelitian ini sesuai dengan pendapat Sudono et al. (2003) dimana peternak yang mempunyai pendidikan yang lebih tinggi akan mudah menerima informasiinformasi yang baru yang sangat berguna untuk meningkatkan efisiensi reproduksi. Sesuai dengan pendapat Notoatmodjo (2003) yang menyatakan bahwa pendidikan adalah suatu kegiatan atau proses pembelajaran untuk mengembangkan atau meningkatkan kemampuan tertentu sehingga sasaran pendidikan itu dapat berdiri sendiri. Pengetahuan dan pengalaman peternak dalam mengelola peternakan menjadi faktor penting terhadap kesehatan reproduksi.

Seseorang yang memiliki pengetahuan dan keterampilan mampu memanfaatkan potensi di dalam maupun di luar dirinya dengan lebih baik, orang itu akan menemukan pekerjaan yang paling tidak setara dengan pendidikannya. Menurut Soekartawi (2003), tingkat pendidikan peternak cenderung mempengaruhi cara berpikir dan tingkat penerimaan mereka terhadap inovasi dan teknologi baru.

Pengalaman beternak juga berperan penting selain pendidikan peternak. Hal ini disebabkan karena pengalaman beternak akan menghasilkan suatu kebiasaan yang akan mempengaruhi peternak dalam pola pemeliharaan (Haryadi, 1998). Menurut Fauziah dan Tumpubolon (1991) dalam Siregar (2009), 
pengalaman seseorang dalam berusaha tani berpengaruh terhadap penerimaan dari luar, lamanya pengalaman diukur mulai sejak kapan peternak itu aktif secara mandiri mengusahakan usaha taninya tersebut. Mastuti dan Hidayat (2008) menyatakan bahwa semakin lama beternak diharapkan pengetahuan yang diperoleh semakin banyak sehingga keterampilan dalam menjalankan usaha peternakan semakin meningkat.

\section{Letak Kandang dari Rumah}

Letak kandang dari rumah bermakna $(\mathrm{P}=0,081)$ dan berasosiasi positif terhadap kejadian RB sebesar 0,090, dapat dilihat pada Tabel 2. Hal ini berarti bahwa semakin jauh jarak kandang dengan rumah maka dapat semakin meningkatkan nilai RB. Kandang yang terlalu jauh dari rumah menyebabkan kurangnya pengawasan peternak dalam manajemen pemeliharaan, karena peternak melakukan pemberian pakan dan deteksi birahi pada waktu malam hari, deteksi birahi dilakukan dengan cara mengamati tingkah laku ternak seperti kurangnya nafsu makan, sering bersuara, ternak merasa gelisah serta mengeluarkan cairan berwarna putih bening dan kental. Deteksi birahi yang dilakukan pada saat malam hari tidak maksimal, hal tersebut dikarenakan kurangnya pencahayaan. Apabila sapi mengalami birahi pada pagi atau siang hari dan peternak mendeteksi birahi pada malam, maka terjadi keterlambatan waktu mendeteksi. Hal tersebut dapat menyebabkan keterlambatan dalam melakukan IB sehingga meningkatkan nilai RB pada ternak. Perkawinan yang dilakukan terlalu cepat atau lambat dapat menurunkan angka kebuntingan. Perkawinan yang terlalu cepat menyebabkan terlalu lamanya spermatozoa menjadi tua dan kemampuannya rendah untuk membuahi (Noakes et al., 2009).

Siregar (2003) menyatakan bahwa kandang yang baik tidak berdekatan dengan pemukiman, memiliki penanganan limbah dan ketersediaan air. Lokasi yang ideal untuk membangun kandang adalah daerah yang letaknya cukup jauh dari pemukiman penduduk tetapi juga mudah dicapai oleh kendaraan (akses menggunakan kendaraan dapat dijangkau dengan baik). Kandang harus terpisah dari rumah tinggal dengan jarak minimal $10 \mathrm{~m}$ dan sinar matahari harus dapat menembus kandang atau kandang secara keseluruhan dapat terkena sinar matahari dengan baik (Kemenristek, 2005). Rata-rata letak kandang dari rumah di Kecamatan Pesisir Selatan Kabupaten Pesisir Barat yaitu $12,3 \mathrm{~m}$.
Letak kandang yang terlalu dekat dengan pemukiman juga tidak disarankan, karena selain mengganggu aktivitas manusia juga dapat mengganggu kenyamanan ternak itu sendiri. Dekatnya letak kandang dengan pemukiman mengakibatkan sirkulasi udara yang tidak baik. Menurut Santosa (2004), sirkulasi udara yang kurang baik secara terus menerus menyebabkan gangguan fisiologis kesehatan, sapi menjadi tercekam panas karena sapi merasa tidak nyaman dengan kondisi lingkungan yang dapat menyebabkan terjadinya penurunan produktivitas. Menurut Hartati dan Ainur (2007), konstruksi kandang yang baik untuk ternak harus kuat, mempunyai sirkulasi udara yang baik dan konstruksi kandang harus mampu menahan beban benturan dan dorongan yang kuat dari ternak sehingga ternak merasa nyaman, serta menjaga keamanan ternak dari pencurian.

\section{Umur Pertama Kali Dikawinkan}

Rata-rata umur pertama kali dikawinkan pada Sapi Krui di Kecamatan Pesisir Selatan Kabupaten Pesisir Barat dapat dilihat pada Tabel 2. Berdasarkan Tabel 2, rata-rata umur pertama kali dikawinkan pada Sapi Krui adalah 26,40 bulan. Umur pertama kali dikawinkan bermakna $(\mathrm{P}=0,069)$ dan berasosiasi negatif terhadap kejadian RB sebesar 1,088, dapat dilihat pada. Hal ini berarti bahwa semakin lama sapi dikawinkan untuk pertama kalinya maka akan menurunkan nilai RB. Ternak yang terlalu muda saat perkawinan pertama akan menyulitkan terjadinya kebuntingan karena perkembangan fisiologi ternak tersebut belum sempurna. Hal tersebut disebabkan karena nutrisi yang masuk di dalam tubuh ternak yang belum dewasa akan digunakan untuk fungsi pokok terlebih dahulu yaitu untuk pertumbuhan tubuh. Toelihere (1981) menganjurkan bahwa perkawinan dilakukan setelah dewasa kelamin. Hal tersebut disebabkan ternak yang baru mengalami pubertas masih banyak membutuhkan nutrisi untuk perumbuhan tubuh. Selain itu, kinerja organ reproduksi untuk menghasilkan hormon masih belum sempurna sehingga biasanya dalam deteksi birahi kurang jelas. Perkawinan pertama pada sapi dara sebaiknya dilakukan pada umur 12-15 bulan (Toelihere, 1981). Wahyudi et al. (2013) lebih lanjut menyatakan bahwa tingkat kesuburan ternak juga dipengaruhi oleh umur ternak tersebut, semakin tua umur induk maka reproduksi semakin baik dibandingkan dengan induk muda. Kinerja organ reproduksi untuk menghasilkan hormon optimal pada saat sapi mencapai umur 2,5 tahun, jadi jika sapi dikawinkan kurang dari 2,5 tahun maka akan 
meningkatkan RB Siklus birahi yang tidak teratur cenderung terjadi jika sapi dara belum dikawinkan pada umur 4 tahun dan menyebabkan penurunan prestasi reproduksi (Hardjopranjoto, 1995).

\section{Penerapan Model}

Hasil analisis logistik regresi dari faktorfaktor yang mempengaruhi repeat breeder pada Sapi Krui di Kecamatan Pesisir Selatan Kabupaten Pesisir Barat dapat diformulasikan sebagai berikut:

$$
\begin{aligned}
\mathrm{Y}= & 4,485-5,757(\mathrm{X} 10)+0,090(\mathrm{X} 18)-1,088 \\
& (\mathrm{X} 26)
\end{aligned}
$$

Keterangan:

$$
\begin{array}{ll}
\mathrm{Y} & =\text { nilai duga repeat breeder } \\
\mathrm{X} 10 & =\text { pendidikan peternak } \\
\mathrm{X} 18 & =\text { letak kandang dari rumah } \\
\mathrm{X} 26 & =\text { umur pertama kali dikawinkan }
\end{array}
$$

Penerapan model faktor-faktor yang mempengaruhi RB pada Sapi Krui yang berasal dari peternak dan ternak dengan rata-rata nilai kondisi nyata di lapangan adalah:

$$
\begin{aligned}
\mathrm{Y}= & 4,485-5,757(\mathrm{X} 10)+0,090(\mathrm{X} 18)-1,088 \\
& (\mathrm{X} 26) \\
= & 4,485-5,757(1)+0,090(12,3)-1,088 \\
& (18) \\
= & 4,485-5,757+1,107-19,584 \\
= & -19,749
\end{aligned}
$$

Hasil di atas dapat diartikan bahwa peternak yang memelihara Sapi Krui dipelihara oleh peternak pendidikan SD, dengan letak kandang 12,3 m dari rumah dan umur sapi pertama kali dikawinkan 18 bulan dapat menurunkan nilai RB sebesar 19,749. Penerapan model faktor-faktor yang mempengaruhi RB pada Sapi Krui yang berasal dari peternak dan ternak dengan keadaan ideal adalah:

$$
\begin{aligned}
\mathrm{Y}= & 4,485-5,757(\mathrm{X} 10)+0,090(\mathrm{X} 18)-1,088 \\
& (\mathrm{X} 26) \\
= & 4,485-5,757(3)+0,090(23,8)-1,088 \\
& (26,40) \\
= & 4,485-17,271+2,142-28,723 \\
= & -39,367
\end{aligned}
$$

Hasil di atas dapat diartikan bahwa peternak yang memelihara Sapi Krui dengan latar belakang pendidikan SMA, dengan letak kandang 23,8 m dari rumah dan umur sapi pertama kali dikawinkan 26,40 bulan dapat menurunkan nilai RB sebesar 39,36.

\section{SIMPULAN DAN SARAN}

\section{Simpulan}

Simpulan yang diperoleh pada penelitian ini adalah:

1. Kejadian repeat breeder pada Sapi Krui di Kecamatan Pesisir Selatan Kabupaten Pesisir Barat adalah sebesar 10,24\%.

2. Faktor-faktor yang mempengaruhi repeat breeder pada Sapi Krui di Kecamatan Pesisir Selatan Kabupaten Pesisir Barat berasal dari peternak (pendidikan peternak dan letak kandang dari rumah), dan ternak (umur pertama kali dikawinkan).

\section{Saran}

Pemerintah daerah khususnya dinas terkait dapat memberikan pelatihan terhadap peternak mengenai manajemen pemeliharaan dan manajemen reproduksi pada Sapi Krui.

\section{DAFTAR PUSTAKA}

Astuti, H.Y. 2008. Faktor-faktor yang Mempengaruhi Repeat Breeder Pada Sapi Potong di Kecamatan Terbanggi Besar Kabupaten Lampung Tengah. Skripsi. Fakultas Pertanian. Universitas Lampung. Bandar Lampung

Copelin, J. P., M. F. Smith, H. A. Garveric, R. S. Youngguist, M. Vey, and E. K. Inskeep. 1988. Responsivenes of bobine corpus luteum to PGF 2 $\alpha$ : Composition of corpora lutea anticipated to have short of normal lifesspans. J. Animal Science. 26(5): 1236-1246

Dinas Pertanian Kabupaten Pesisir Barat. 2018. Tabel Populasi Sapi Krui. Dinas Pertanian Kabupaten Pesisir Barat. Pesisir Barat

Direktorat Jenderal Peternakan dan Kesehatan Hewan. 2018. Statistik Peternakan dan Kesehatan Hewan. Direktorat Jenderal Peternakan dan Kesehatan, Kementerian Pertanian. Jakarta

Gustafsson, H. and U. Emanuelsson. 2002. Characterisation of the Repeat Breeding Syndrome in Swedish Dairy Cattle. Journal Acta Vet Scand 43(2): 115--125

Hardjopranjoto, H. S. 1995. Ilmu Kemajiran pada Ternak. Airlangga University Press. Surabaya

Hartati dan R. Ainur. 2007. Petunjuk Teknis Perkandangan Sapi Potong. Pusat Penelitian dan Pengembangan 
Peternakan. Lokal Penelitian Sapi Potong Grati Pasuruan

Haryadi, F. T. 1998. Efektivitas penyuluhan sapta usaha peternakan sapi potong pada dua model perkampungan ternak. Jurnal Buletin Peternakan 23(3): 11-19

Juliana, A., M. Hartono dan S. Suharyati. 2015. Repeat breeder pada sapi Bali di Kabupaten Pringsewu. J. Ilmiah Peternakan Terpadu 3(2): 42--47

Kementerian Riset dan Teknologi. 2005. Budidaya Sapi Potong. Kemenristek. Jakarta

Mastuti dan Hidayat. 2008. Peranan tenaga kerja perempuan dalam usaha ternak sapi perah di Kabupaten Banyumas. $J$. Animal Production. 11(1): 40-47

Noakes, D. E., T. J. Parkinson, and G. C. W. England. 2009. Veterinary Reproduction and Obstretrics, Ninth ed. Edinburgh London Elsevier. London

Notoatmodjo, S. 2003. Pendidikan dan Perilaku Kesehatan. Rineka Cipta. Jakarta

Robert, S. J. 1986. Infertility in The Cows. In Veterinary Obstetric and Genetical Disease (Theriogenology). $3^{\text {rd }}$ edition Published by the author, Woodstock, VT 05091 Ithaca. New York

Santosa, U. 2004. Aplikasi Manajemen Pemeliharaan Bibit Induk Sapi Potong pada Peternakan Tradisional. Dinas Peternakan Provinsi DT I. Bandung.

Siregar, S. B. 2003. Teknis Pemeliharaan Ternak Sapi dan Analisis Usaha. Penebar Swadaya. Jakarta

Siregar, S. A. 2009. Analisis Pendapatan Peternak Sapi Potong di Kecamatan Stabat Kabupaten Langkat. Skripsi Jurusan Ilmu Produksi Ternak Fakultas Peternakan Universitas Sumatera Utara. Universitas Sumatera Utara

Soekartawi. 2003. Teori Ekonomi Produksi dengan Pokok Bahasan Analisis CobbDouglas. PT Raja Grafindo Persada. Jakarta

Sudono, A., F. Rosdiana, dan B. S. Setiawan. 2003. Beternak Sapi Perah Secara Intensif. Agromedia Pustaka. Jakarta

Toelihere, M.R. 1981. Ilmu Kemajiran pada Ternak Sapi, Edisi Pertama. Institut Pertanian Bogor. Bogor . 1983. Inseminasi Buatan pada Ternak Perah. Angkasa. Bandung

Wahyudi, L., Susilawati, T. dan Wahyuningsih, S. 2013. Tampilan Produksi Sapi Perah pada Berbagai Paritas di Desa Kemiri Kecamatan Jabung Kabupaten Malang. J. Ternak Tropika. 14(2): 13-22
Windig J. J., Calus, R. F. Veerkamp . 2005. Influence of Herd Environment on Health and Fertility and Their Relationship with Milk Production. $J$ Dairy Sci 88: 335-347

Yuliana. 2000. Faktor-faktor yang Mempengaruhi Repeat Breeder Sapi Perah di Koperasi Peternakan Bandung Selatan Pengalengan Bandung Jawa Barat. Skripsi. Fakultas Pertanian. Universitas Lampung. Bandar Lampung 